\section{Applications of geomorphology}

Applied Geomorphology: A Perspective of the Contribution of Geomorphology to Interdisciplinary Studies and Environmental Management. Edited by John R. Hails. Pp. xv +418 . (NorthHolland: New York, Amsterdam and Oxford, 1977.) \$39.95; Dfl.98.00.

ThE descriptive models of landscape evolution written in the sonorous prose of the last century were debated but only a little refined over 50 years, with too little attention being paid (though there were exceptions) to the mechanics of the processes invoked in sculpting type forms of the land surface. In comparatively recent years, enormous strides forward have been made, largely by application of quantitative methods in the laboratory and in the field. The subject is becoming established as a science in its own right, and though still interdisciplinary between civil engineering, geology and geography, the applied aspects compel its inclusion in optimisation of land use, in building science, and in pedology.

The subtitle of the book truly indicates the contents, written by nine authors, each an acknowledged leader in his field and (as in the editor's introduction) able to "communicate ideas comprehensible to others who have no geomorphological knowledge".

Some authors discuss widely, as in the chapter on weathering, with applications ranging from ore deposits to geomedicine, whereas others present thorough yet succinct summaries of their discipline; a very creditable example of this is the chapter on "Periglacian Environments". The chapter on irrigation and ground-water studies demonstrates how the success of irrigation schemes would be enhanced if designed to fit the geomorphic units compiled from interpretation of the geomorphic history of the area. Processes controlled by climatic differences have less importance in Karst hydrology, as the author of that chapter makes quite clear; he also cites Sweeting's view that the study of the development of Karst landforms has probably been hindered less by the dominance of cyclic ideas than by the lack of contact of workers in the different Karst regions. From work initially conceived in a spirit of academic enquiry, there is now much of importance to the engineer involved in dam building or using limestone aquifers as reservoirs or quarries for waste disposal.

The chapter on fluvial hydrology explains the relation between some of the many variables to be measured in comprehending the river as an integration of the catchment morphology. Man's use and modification of rivers has often proved needlessly expensive in corrective measures applied where these measures opposed the natural forces.

The same can be said of the problem of routing motorways, with examples in the chapter on soil mechanics of slopes. The degree of stability of previously stable slopes cannot yet be predicted.

It seems paradoxical in the chapter on deserts to see the stress on removal of sediments by water: though widely spaced in time, these processes are critical in terrain classification and environment.

For resource appraisal, trafficability and management problems, systems of terrain classification, with subgroups of land units, are explained using block diagrams, maps and tables to help comparison of different methods and applications.

A chapter on coastal zone planning and management includes sea defences,

\section{Differentiation in cellular slime moulds}

Development and Differentiation in the Cellular Slime Moulds. Edited by P. Cappuccinelli and J. M. Ashworth. Pp. $x x+317$. (Elsevier/North Holland: Oxford, New York and Holland, 1977.) Dfl. $79 ; \$ 39.75$.

ThIs volume is a collection of papers from an EMBO workshop held in April 1977. One is grateful that it has been published so quickly, but this advantage is somewhat diluted by the way in which the book is printed. The typewritten manuscripts have been directly photocopied and greatly reduced; as a result some of the papers are either so faint or the print so small that they require hard work to read. What with the high price of the volume, the least the publishers could have done is to issue a magnifying glass with each copy, like the compact edition of the Oxford English Dictionary.

Cellular slime moulds are having a burst of popularity, and this excellent collection of papers gives one a good view of current progress. Many of the papers are mixtures of reviews and new results, some of the latter being significant advances.

To show where the main interests lie at the moment, I have made a list of the areas covered in the symposium: six of the papers are on some aspect of differentiation; five on cyclic AMP pulsations and their various effects in- off-shore banks and beach stability, and discusses how these can be affected by tourist use, by mining and by construction works.

Inevitably, the great range of style and subject matter compels dipping into the book for a synopsis of specific aspects; but the 20 pages of index are inadequate for the reader looking for specific topics across different chapters - for example, rates of rock wear or removal by different geomorphic processes. The 35 pages of references are very valuable and would have been doubly so if the page number could have been added to indicate where referred to in the text.

There are numerous maps, tables and graphs and nine half-tone plates, leavening a most valuable summary of some quite difficult branches of this global science.

H. Lister

H. Lister is Reader in Physical Geography at the University of Newcastle upon Tyne, $U K$.

cluding their role in chemotaxis; four studies which in some way relate to problems of transcriptional and translational control of protein synthesis; three on different aspects of genetics; two on the plasma membrane; and one each on cell contact, cell division, polyamines, and modelling biochemical pathways.

One theme that runs through a number of papers is the role of cell contact on different aspects of development. J. Gross et al. found that cell attachment during aggregation, the rate of cyclic AMP signalling and the appearance or disappearance of certain proteins, all change at the same time. H. V. Rickenberg et al. show that cell contact is not necessary for the synthesis of alkaline phosphotase in cells grown in liquid culture if the suspension of separate cells is pulsed with cyclic AMP. H. F. Lodish and T. H. Alton provide evidence suggesting that at early stages when cells are separate, protein synthesis is controlled at translation, since there are numerous mRNAs present which are not translated. At aggregation, however, transcriptive control takes over and all the mRNAs are directly used to make new protein.

It is fitting that this interesting collection of papers should be dedicated to Kenneth Raper who discovered Dictyostelium discoideum and led the way in showing the exceptional usefulness of cellular slime moulds as experimental organisms.

J. T. Bonner

J. T. Bonner is Professor of Biology at Princeton University, New Jersey. 